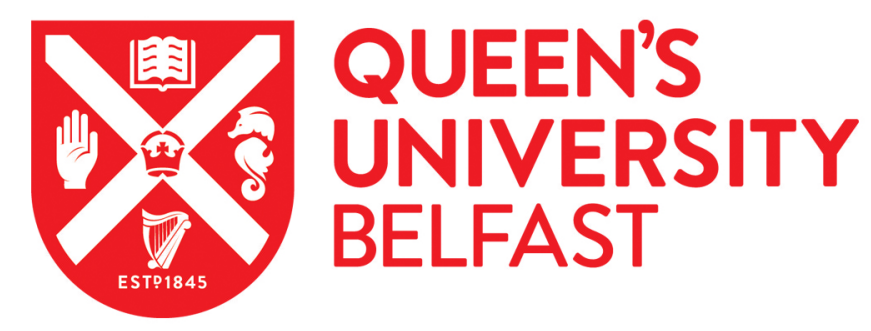

\title{
An exploration of the emotional impact of organisational ethnography
}

Mazzetti, A. (2016). An exploration of the emotional impact of organisational ethnography. Journal of Organizational Ethnography, 5(3), 304-316. https://doi.org/10.1108/JOE-07-2016-0018

Published in:

Journal of Organizational Ethnography

Document Version:

Peer reviewed version

Queen's University Belfast - Research Portal:

Link to publication record in Queen's University Belfast Research Portal

Publisher rights

(c) Emerald Group Publishing Limited 2016. This work is made available online in accordance with the publisher's policies. Please refer to any applicable terms of use of the publisher.

\section{General rights}

Copyright for the publications made accessible via the Queen's University Belfast Research Portal is retained by the author(s) and / or other copyright owners and it is a condition of accessing these publications that users recognise and abide by the legal requirements associated with these rights.

Take down policy

The Research Portal is Queen's institutional repository that provides access to Queen's research output. Every effort has been made to ensure that content in the Research Portal does not infringe any person's rights, or applicable UK laws. If you discover content in the Research Portal that you believe breaches copyright or violates any law, please contact openaccess@qub.ac.uk. 


\title{
An Exploration of the Emotional Impact of Organisational Ethnography
}

\author{
Abstract \\ Purpose: The purpose of this paper is to highlight the diverse and strong emotions \\ experienced by the researcher when conducting an ethnographic study in an organisational \\ setting.
}

Design/methodology/approach: In this paper extracts from research diaries written over a three year organisational ethnography study period are presented to the reader.

Findings: This paper provides an insight into the range of emotions that are experienced throughout the various stages of the research process from securing access, to conducting fieldwork and writing up research for publication.

Practical implications: It is hoped that the sharing of emotional experiences will better prepare new organisational researchers for the emotions they may experience in the field. Limitations: Although this paper focuses on organisational ethnography, comparisons are drawn with related disciplines and as such, this paper may also be of interest to those conducting ethnographic studies in other fields.

Originality / Value: There is a recognised need for more sharing of emotional experience in organisational studies. It is hoped that this paper goes some way to highlighting these emotional challenges and will therefore provide a catalyst for other researchers to do the same.

Keywords: ethnography, emotion, ethnographic research, organisational ethnography, researcher emotion. 


\section{Introduction}

Conducting an ethnographic study is an emotional experience which can have longlasting impact on the researcher (Van Maanen, 2010a). Emotions may be experienced throughout the ethnographic research process including gaining access (Brewer 2000; Crang and Cook, 2007); fieldwork (Down et al., 2006; Mohrman, 2010; Waddington, 2004) and writing up (Van Maanen, 2010b; Waddington, 2004). Yet within the field of organisational studies, this emotion is rarely expressed in academic writing (Clarke et al., 2014; Down et al., 2006; Whiteman et al., 2009). With limited role models to draw on, this may result in new ethnographic researchers being unprepared for the emotions they may encounter (Van Maanen, 2010a; Whiteman et al., 2009). Researchers may therefore feel that their emotional experiences are not normal and that they are in some way inadequate (Down et al., 2006). Ultimately, without appropriate guidance and support, researchers may lose faith and eschew ethnographic research in favour of other methodologies (Van Maanen, 2010a).

This paper draws on both the literature on researcher emotion and my own personal experiences of planning, conducting, and writing up ethnography, to explore the emotions experienced when conducting an ethnographic study. This paper is structured in three sections. First a review of the literature on researcher emotion is presented. Second a series of research diary extracts taken during a three year ethnographic study of an independent fire training centre and three fire and rescue services in England are presented. These extracts have been selected to illustrate the strength and diversity of emotions I experienced during the different stages of the research study. Finally the implications for practice are discussed and suggestions to support new researchers are put forward. Rather than a focus on one specific emotion or on one specific phase of the research process, this paper explores the range of emotions that are experienced during the various phases of an enthnographic study. It is hoped that this paper will go some way to highlight the 'reality' (Moeran, 2009) rather than the 'varnish' (Fine and Shulman, 2009) of fieldwork and therefore reduce the emotional “shock impact"' (Van Maanen et al., 1993) by better preparing ethnographic researchers for the emotions they may encounter in the field. 


\section{Researcher Emotion}

Organisational ethnography has made significant progress and impact over the past twenty years (Van Maanen, 2010b) and the insights provided by these studies has significantly contributed to our understanding of organisational life (Ybema et al., 2009). It is therefore important that researchers conducting organisational ethnographies are appropriately prepared and supported throughout their research to enable further advancements to be made (Van Maanen, 2010a). Although researcher emotion is explicitly discussed in other disciplines (for example, see Dickson-Swift et al., 2008 for a contemporary review in health research and Milton and Svašek, 2005 for a contemporary review in anthropological research) there remains limited reference to researcher emotions within the discipline of organisational studies (Broussine et al., 2014; Clarke et al., 2014; Mazzetti, 2013; Whiteman et al., 2009). As such, Whiteman et al. (2009, p. 47) suggest that discussions on the issue are more likely to be 'back stage' and secretive discussions with the majority of published accounts within the discipline remaining "sanitized, emotion-less texts". Consequently, insufficient attention is paid to the discussion of emotions within the organisational studies academic community (Brannan, 2014; Clarke et al., 2014; Whiteman et al., 2009). However, Whiteman et al. (2009) suggest that this is an 'intriguing gap' given the strong and diverse emotions experienced in the field. Indeed, Broussine et al. (2014) highlight that if we accept that emotions are embodied and embedded in everything that humans do, then the literature on 'how to' conduct research should be replete with references to emotions as all organisational research involves human researchers and human participants.

Brannan (2014, p. 21) suggests that organisational ethnographies are not only a wellsuited methodology for capturing the experiences of a contemporary workplace but also "a potentially rich and hitherto untapped source of insights into the emotional dimensions of fieldwork". However, Koning and Ooi (2013) note that ethnographic studies of organisations rarely discuss the emotions and awkwardness experienced in the field. Researchers suggest that there are a number of reasons why the emotions of fieldwork are rarely discussed.

First, in an academic culture dominated by 'objectivity' and 'science', researchers may feel that exposing their emotions may bring into question the 'trustworthiness' of their research (Kleinman, 1991; Kleinman and Copp, 1993; Watts, 2014). Brannan (2014, p. 31) suggests that the "rational / objectivist current remains strong" in organisational ethnography and as such the rational is privileged over the emotional. He suggests that early career researchers may therefore marginalise their feelings in an attempt to demonstrate intellectual 
rigour and researcher competence. Whiteman et al. (2009) further suggest that this creates a void as there are few incentives for researchers to share their emotional stories. This may lead researchers to write in a sanitized way with even those who are willing to discuss their emotions in their writing, experiencing difficulties in finding the right words to articulate their feelings (Brannan, 2014) and translating their emotional encounters into a textual narrative (Whiteman et al., 2009).

Second, ethnographers rarely want to share the awkwardness of their research encounters (Koning and Ooi, 2013). Citing Goffman (1989) Fine and Shulman (2009, p. 188) suggest that although a "good ethnographer must willingly look like a 'horse's ass', this is easier said than done. No one wishes to look bad, and self-conscious ethnographers censor much information". They highlight that ethnographers must be encouraged to share "the messiness' of their encounters with the academic community without too much 'tidying up'. However they acknowledge that hidden co-authors in the form of journal reviewers and editors 'police' this problematic writing and in doing so, separate "the polished ethnographic product from its humble origin in fieldnotes". Koning and Ooi (2013) therefore suggest that it is time to take the awkwardness and emotion of ethnographic research seriously.

Finally, there is limited reference to emotions in the guidance presented in methodology texts. Ybema et al. (2009) highlight that many research methods books on organisational ethnography tend to focus on the 'how to' of the process and as such fail to address the 'problematics' encountered during ethnographic research. Clarke and Knight (2014) suggest that the embodied and emotional aspects of conducting research are often omitted from methodological texts which portray research as a rational, linear and mechanistic process. However Broussine et al. (2014, p. 11) note that "research is far more than a predictable process of linear cognitive events. At every stage of the research process, our experiences are marinated in all kinds of emotions". They therefore suggest that any literature guiding 'how to' conduct research should include a discussion of emotion.

Ultimately, the omission of emotion from published works and 'how to' texts results in a lack of role models to follow and perpetuates the status quo within the discipline (Down et al., 2006; Whiteman et al., 2009). This risks researchers being unprepared for the strong and diverse emotions they may encounter in the field (Van Maanen, 2010a; Whiteman et al., 2009) leading researchers to feel inadequate and incompetent when such feelings are experienced (Clarke et al., 2014; Hubbard et al., 2001; Mazzetti, 2013). Ultimately this may result in researchers giving up on ethnography in favour of other research methodologies (Van Maanen, 2010a). 


\section{The Emotional Impact of Conducting Ethnographic Research: Extracts from a Researcher's Diary}

Between 2009 and 2012 I conducted a multi-sited ethnographic study aimed at exploring how occupational culture influenced stress appraisal and coping behaviours. The research was completed as part of my $\mathrm{PhD}$ studies and I worked with four organisations to complete the fieldwork. First, I gained access to an independent fire training centre where I participated in a mix of short and week-long intensive courses. This provided me the opportunity to participate in 'hands-on' basic firefighter training and therefore to get a 'feel' for what it is like to 'fight' fire. Additionally, I gained access to three fire and rescue services in England and although I was not permitted to attend incidents (for example fires or road traffic accidents), I was permitted to participate in a range of activities including accompanying firefighters on fire safety duties, participating in skills-training simulations, participating in community events, and 'hanging out' at the fire stations. Over the three year period, I spend at least one day a week with one of the fire and rescue services which enabled me to participate in the range of day-to-day activities encountered by modern firefighters. In addition I conducted seventeen one-to-one interviews with operational and support managers and twelve focus group interviews with firefighters.

For the duration of the study I kept a research diary to capture my personal reflections of the process. In this section I present five extracts from my diary. Given that this study spanned three years and four different organisations, I amassed a mountain of research data and as such, the extracts presented in this paper represent but a small percentage of that data. However, the extracts have been selected specifically because they reflect both the range of feelings I experienced (frustration, fear, embarrassment, being overwhelmed, guilt) over the different stages (gaining and sustaining access, participating in fieldwork, conducting interviews, writing up the data for publication) of an ethnographic study. As such they are illustrative of the strength of emotions experienced throughout the entire lifecycle of an organisational ethnography. I have removed all names and identifiers from the extracts to protect the identity of both the organisations and the individuals.

\section{Feeling Frustrated: Extract 1: When the best laid plans turn to crud}

This first extract describes the frustration I experienced when a prior agreement to participate in a week-long training programme with the independent fire training centre was disrupted. Before this event, I had already spent some time with this organisation 
participating in a range of training courses. As this course was a week-long event I had to carefully plan both my home and work commitments and as such, prior to this event, I had met with my gatekeeper, a senior manager at the centre, and we had agreed dates, times and level of participation for this course.

I turned up early as arranged to meet XX only to find that he was abroad on business. There was a bit of a flurry of nervous embarrassment as XX's assistant tried to find someone to speak with me. I was invited into a director's office and over a rather tense cup of tea he asked rather bluntly what I was doing here. I soon realised that he was unaware of who I was and unaware of my arrangements with XX. I explained the background to my research and also what I considered to be my arrangements with [organisation name] but which was very clearly starting to emerge as my arrangement with $X X$. He agreed to let the participation in the training event go ahead as planned but that as XX was abroad, he would need to appoint a chaperone to look after me on the fire ground. I was offered another cup of tea and he left the room. After what seemed like an age he returned and explained that at such short notice he was not able to help me today but that I could come back in the morning and work with an appointed chaperone.

I was gutted. I had been planning this for months. I had called in favours both at work and at home - arranging time away, rescheduling appointments, coordinating all sorts of complicated childcare arrangements - all of which was only made possible by my promotion of this event as one of the most significant weeks of my field work. Yet two hours and two cups of lousy tea later I was on my way home. I sat in the car with my head in my hands and I cried. I thought 'why the fuck am I doing this' realising that I had to go home and disturb everyone and say 'hey remember that really important life-changing event that was happening today, well it turns out it's postponed until tomorrow’. Great!

This extract highlights a number of 'problematics' associated with that most tenuous beast - access. First, access issues plagued this study from the start and persisted for the duration of the study. As such this was an ongoing and intensifying frustration as I was constantly negotiating and renegotiating access. Second, this extract highlights that access is often reliant on the goodwill of an individual gatekeeper. In this case the gatekeeper was a long-established contact with whom I had worked for many years; access had therefore been granted based on this friendship and when the gatekeeper was not present, access could be readily withdrawn. Throughout the research project access had to be renegotiated and in some 
cases ceased as my gatekeepers moved on to new roles or organisations. However this extract also highlights a more major issue, perhaps of research naivety. This was the first organisation to agree to participate in the research, but the 'agreement' was with my gatekeeper, not the organisation. Nor had the 'agreement' been formalised in any way. This had the potential to put the researcher, the gatekeeper and the organisation at risk.

\section{Feeling Fear: Extract 2: I'm just a researcher-get me out of here!}

This extract describes the fear experienced when participating in activities that challenge the comfort zone of the researcher. Firefighters often engage in routine training simulations as a means of reviewing their skills and working procedures and during one of my days at the fire station I was asked to participate in such a simulation which involved me acting as a road traffic accident casualty being cut free from a car.

The crews selected a vehicle and manoeuvred it into position and I was squeezed into this wreck of crumpled metal as they retreated to discuss the objectives of the activity. As I sat there on my own for what seemed like an age, I could feel myself getting anxious. One of the crew approached the front of the car. He told me his name and reassured me. He kept telling me to look at him and to ignore anything else going on around me, difficult for an ethnographer trying to take in and remember as much as possible. I became aware of the others (firefighters) around the car starting to lay out equipment. I asked him if there will be sparks. He laughed at me. 'What? With all this fuel?' I hadn't thought of that. I had envisaged being cut from a car would be all sparks and grinding. I felt a bit stupid DOOH!

As they cut free my door, the firefighter was able get his hands in to support my neck. I felt a bit uncomfortable, not because it was painful, but because I had not expected to have a stranger's hands on my neck when I set out on my day. I thought that this must be how it happens in real life. One moment you are driving along happily and the next you have a fireman's hands around your neck. This made it seem all the more real for me. I tried to joke by saying 'You have no idea how many people would like to get their hands round my neck!' in an attempt to lighten the situation which was all becoming a little too real for me.

As they removed the back door he was able to get in the car with me and apply the neck brace. It was tight, very tight, I felt as if I could hardly breathe. [...]I joked about the cold and oh but it was cold. I wanted to pretend that the stuttering of my 
speech was to do with the cold and not the anxiety I was experiencing. He asked if I was ok. I lied. Translate 'yes I'm fine' into 'no I'm fucking scared, cold and not sure how much longer I can put up with this'. [...] I asked him if he could remove the neck brace. He said he couldn't. I felt so uncomfortable. My fire jacket was so bulky I could hardly move, my helmet was cold and tight around my head and the bloody neck brace was stopping me from breathing normally. Why was I doing this? There are much easier ways to spend a Friday afternoon but here I was squashed into a crumpled wreck of metal being strangled by a neck brace that I didn't even need to wear! $[\ldots]$

As I got out from the car, my legs were shaking. The relief must have been evident on my face. I stood there trying to say well done but actually I wanted to say 'Thank fuck I am out of there'. I was so cold that my muscles seized and I couldn't wait to get on that train and go home. I couldn't even talk properly as I was shivering so much. Fuck this ethnography crap! Fuck this ethnography crap!

This extract provides an insight into a range of challenges encountered when conducting an ethnographic study. First, I am not a firefighter but a university lecturer and therefore this activity was very much outside my comfort zone evoking feelings of fear and discomfort. I was not familiar with the procedure or the equipment and therefore did not know what was going to happen at each stage. This lack of knowledge and understanding invoked feelings of anxiety and eventually fear regarding what would happen next.

Additionally the process was uncomfortable. The activity took place outside on an exposed training ground on a cold February afternoon. It was very cold. I was dressed in bulky (for me ) fire kit and squashed into a wreck of a car which had been stripped of any comforts. Indeed, throughout my three year study, I made frequent reference to the weather conditions (being stood for long periods of time in the rain, the cold, and the heat) and fire kit (the bulky protective clothing and heavy equipment such as breathing apparatus). This environment was a far departure from the cosy environment of a university lecturer. Second this extract highlights that during such close contact research, personal resonances can be made. In this case, I was struggling to remember that this was a simulation and not a real incident and as such I was very anxious. Many times throughout this research I encountered situations with which I personally connected, awakening strong emotions of past experiences. However through experiencing these emotions I was able to reflect on these aspects for firefighters. They frequently made reference to the significant impact that malfunctioning equipment and protective clothing had on their ability to perform their tasks effectively in such a high-risk 
environment and throughout our conversations, firefighters frequently discussed the need to remain detached as a coping strategy. These themes may not have been so readily discussed if I had not personally experienced them. Finally, this extract illustrates the 'love / hate' relationship in which researchers engage with their research. Throughout this incident (and others) I questioned my active participation and often reflected that other research methods would be much easier and not so challenging.

\section{Feeling Stupid: Extract 3: Feeling like a horse's ass}

This extract describes the feelings of inadequacy experienced when participating in activities that are new and unfamiliar. The extract describes my first day of fire training at the independent fire training centre. After a morning in the classroom going through various scenarios and procedures, I was dressed in fire kit and taken to the fire ground to put this training into practice. I was accompanied by the trainer and two assistants (the fire-starters) who were responsible for setting up the fires. The extract starts after I had completed my first fire scenario.

My next fire was a chip-pan fire which I had to extinguish with a fire blanket. The fact that I had to use a fire blanket meant that I had to get much closer to the fire. As I approached the pan I could feel such immense heat. As I approached I caught sight of the fire-starters smiling at one another which I interpreted as 'What a wussy!' [...] The flames were going so high and even though I was covered head to toe in fireretardant protection, I could still feel the heat of the fire. I finally put the fire blanket over the pan and the fire was out.

The next fire was much bigger. Again, the heat was incredible and the longer I left it (it was literally seconds of hesitation) the more fierce the fire became. As I got more nervous, I seemed to lose my coordination and couldn't work the fire extinguisher. The fire was getting bigger and bigger. 'Get in there lass and put that bloody fire out' yelled XX as he pushed me towards the fire. I found myself stood in front of this bloody fire with flames as big as me. I seemed to freeze. The fire-starters moved forward. Not so bloody smug now! Then I felt XX put his arms around me and walk me towards the fire and put his hands on the extinguisher to help me. The fire was out but I felt such a failure.

This extract provides an insight into some of challenges encountered when conducting an ethnographic study in an unfamiliar organisation. Similar to the previous extract, I was in an unfamiliar environment and therefore pushed (literally in this case) out of my comfort 
zone. However, this extract also highlights how others did not share my enthusiasm for my research. The 'fire-starters' and the trainer were somewhat amused by the process. On more than one occasion throughout the research, others questioned, ridiculed and dismissed my research. At times, this even included university colleagues who were unfamiliar with ethnographic research.

\section{Feeling Overwhelmed: Extract 4: The researcher and her other selves}

This extract highlights the difficulties in trying to maintain balance between the time spent on research and the time needed to spend performing other roles such as 'worker', 'mother' and 'wife'.

Sometimes I struggle to have balance. There are work priorities and home priorities and sometimes they all just clash together and I feel as if I have achieved nothing. Sometimes I feel so frustrated with it all. It seems like such a high mountain that will never be scaled. But other times I feel more focused and cover a lot of ground. On other days I am so distracted and totally obsessed with thoughts of my research that I struggle to focus on anything else. Some days I think 'Do I really have to pick CJ up from school?' 'Do we really need to eat tonight?' ' Can someone else please feed the bloody cat!'

The nature of ethnographic study involves intense periods spent in the field and as such blurs the boundaries with the other roles performed by the researcher. As a part-time researcher in full-time employment and a full-time relationship with caring responsibilities, there were many periods throughout the study when it was difficult to achieve a balance leading to a feeling of being overwhelmed. It is important to be realistic and implement practical solutions which may help to maintain a sense of equilibrium.

\section{Feeling Guilty: Extract 5: Opening cans of worms}

This next example highlights a recurring ethical concern I encountered throughout the research, that discussions about traumatic events would have a harmful impact on my research participants.

They all talked about a recent incident they had attended. The incident came up again and again throughout the interview and again I wondered about how ethical my work was as I was reminding them of traumatic events. Unintentionally, but they were still being discussed. What impact might this have on them? And on me? But I also considered how much of this is group counselling for them? Coming to terms 
with the incident? Giving each other reassurance that the incident was handled correctly and that they had done all they could? It reminded me of XX's comments about how as a firefighter you always ruminate on the action you have taken. Maybe these discussions are therefore part of this process and therefore therapeutic? But how can I be sure?

This extract highlights the feelings of guilt often experienced by ethnographic researchers that their research will in some way harm their participants. This was a particular issue for this study as both the topic (stress and coping) and the context (fire and rescue service) heightened the potential to be engaging in sensitive conversations. These feelings of guilt did not subside after the field work stage but continued in the text work stage. I was presented with a number of challenges in deciding what, how and where to publish the findings of the study whilst trying to ensure the anonymity of both the organisations and individuals involved.

\section{Discussion}

In this paper I have presented a number of extracts that highlight the range of emotions experienced at the various stages of conducting an ethnographic study. These five extracts highlight key issues which I feel should be considered by researchers and their supervisors in the design, execution, and writing up of ethnographic studies. Some of these findings complement and further develop the work of others and as such connections are made where appropriate to this literature. However some findings also provide new insights into less-explored aspects of the research process. Each of these issues will now be discussed in more detail.

Extract one is illustrative of the access challenges that persisted throughout my research. A number of authors have acknowledged the challenges posed by trying to gain access for example, Moeran (2007) suggests that gaining access is probably the most difficult and tense part of fieldwork. However, given that the main method adopted in ethnography is participant observation which involves the immersion of the researcher in the natural social setting of the research participants usually on a long-term basis (Emerson et al., 2001; Hammersley and Atkinson, 2007), I would suggest that the very nature of ethnographic research intensifies access issues. This is because organisational ethnographers are not simply trying to gain short-term access to conduct a series of interviews or administer a questionnaire, but rather asking an organisation to commit to a more long-term and more 
intensive (and perhaps intrusive) relationship. As noted in extract one, as a mature researcher I had a long-established professional network to draw on and I was able to personally contact quite senior gatekeepers to discuss access. But still I had rejections, false starts and one contact that never even replied to my emails or returned my calls. Gaining access therefore requires us to be persistent and resilient and research supervisors and colleagues may need to provide very practical support in terms of facilitating networking opportunities and also emotional support to encourage us when challenges are encountered.

However extract one also highlights that access is about more than getting your foot in the door; it is also about sustaining access through the development of relationships with gatekeepers . Moeran (2007) highlights the significance of having the right gatekeeper within the organisation as this person will determine the kind of access in terms of the types of activity researchers can be involved with and also restrictions on which employees can be interviewed. Certainly, I found that my level of participation varied across the four organisations and was dependent on both my personal relationship with my gatekeeper and also their position within the organisation hierarchy and therefore their degree of autonomy and decision making latitude. Fine and Shulman (2007, p. 179) highlight that "ethnographers are more often beggars than choosers" when it comes to access and as extract one illustrates, even when access has been granted by a senior manager within an organisation, access may still be withdrawn or restricted by those more senior in the organisational hierarchy particularly when there is no formal agreement in place. Schwartz-Shea and Yanow (2007) therefore note that researchers need to be guided not only on how to gain access but also on the measures that can be taken to sustain access. Access to two of my research organisations was fairly informal but as a result (as highlighted in extract one) the access was also rather tenuous and temporal. As such I put in place a written agreement with subsequent organisations to manage both my expectations and the organisations'. Additionally, Moeran (2007) highlights that most organisations will be interested in 'what's in it for us' and therefore the researcher has to be able to offer something back to the organisation which Schwartz-Shea and Yanow (2007) suggest may involve researchers volunteering for a variety of participatory projects and activities which not only enables them to give back but also helps them to sustain a positive relationship with the organisation.. Indeed for two of the fire and rescue services I volunteered to administer questionnaires, conduct focus groups and present a series of management reports as a means of offering something back in exchange for access. These activities were agreed at the start of the access period and were formalised as a written agreement between the researcher and the organisation. 
Extract two focuses on a less-debated issue within the literature, that being attuned to our 'emotional radar' (Whiteman et al., 2009) can help us to make a connection with issues that otherwise may go unexplored. My constant references to feeling cold, wet, hot, and uncomfortable enabled me to explore these issues in depth with the firefighters. As such a key finding from this research study was the multisensory nature of appraisal and therefore the significance that firefighters attach to 'fit for purpose' equipment and clothing in such a high-risk context. By personally connecting with these issues, I was better able to connect with my participants which ultimately led to new insights and understanding (Kleinman and Copp, 1993). Extract two therefore highlights that emotions are an integral part of ethnography and as such should be readily acknowledged and explored and discussed 'front stage' rather than remaining hidden and covered up 'back stage' (Whiteman et al., 2009).

Extract three highlights an issue that has received some attention within the literature; that not all of our participants will share our interest for our research. Due to the nature of ethnographic studies, participants are less able to opt out (Hammersley and Atkinson, 2007) and as such, not all participants will be welcoming of the researcher (Brewer, 2000). Although I encountered many enthusiastic and engaged participants, I also encountered those who were rude and dismissive (see Mazzetti, 2013 for examples). It is therefore important that we do not hold onto a romanticised view that we will develop a rapport with all our participants and therefore we have to accept that not every encounter with participants will be a positive one (Kleinman, 1991). For example, Dundon and Ryan (2010) highlight that ethnographers can often encounter participants who are reluctant to engage with the research. They suggest that this reluctance can take the form of participants being unwilling to be 'interviewed' and who therefore deny access or those who agree to be interviewed but then are reluctant to disclose information as the interview progresses. They further suggest that depending on the nature of the research, participants may become defensive and protective of both themselves and their colleagues. They suggest that in such situations, researchers search for commonalities between themselves and participants in order to develop a better rapport.

In extract four I explore the impact that long-term participation in an unfamiliar environment has on the researcher, an issue that has received limited coverage in the literature on ethnography. I often felt exhausted and overwhelmed by my research, feelings which were exacerbated during those periods of intensive participation. Ethnography is far from a linear process (Crang and Cook, 2007) and the varied activities of participation, interviewing, taking fieldnotes and reflection all merge and at times collide. It is therefore important that researchers and supervisors take practical steps to alleviate feelings of 
exhaustion and being overwhelmed through for example the timing and scheduling of activities and the negotiation of deadlines. Additionally, the focus on participant observation within the field of organisational ethnography results in intense periods spent in the field. In my case this meant taking on an additional role to my existing work and personal roles. As such I often experienced conflicting role demands which further exacerbated my feeling of being overwhelmed. It is therefore vital that researchers and supervisors explore the full range of methods available when designing ethnographic studies. For exampleYbema et al. (2009) highlight that the nature of ethnography is changing and as such, researchers will be more likely to engage in more fragmented and diffuse ethnographies. Additionally Pink (2009, p. 9) highlights that while the classical observational method provides valuable insights into the lives of others, "this type of fieldwork is often not viable in contemporary contexts" because of a number of practical constraints and limitations. For example, "due to constraints of time and other practical issues impacting on the working lives of ethnographers as well as those of research participants". Pink $(2009$, p. 9) therefore suggests that this has meant that "innovative methods have been developed by ethnographers to provide routes into understanding other peoples' lives, experiences, values, social worlds and more that go beyond the classical observational approach".

In my final extract I explore the feelings of guilt that I experienced throughout my research. Fine and Shulman (2007, p. 187) suggest that "to do no harm is a prime injunction for all ethnographers. Yet we do leave tracks." The emergent nature of ethnographic research means participants can shape the direction of the conversation and researchers may find themselves trespassing into territory they had not anticipated (Hoffmann, 2007; Hubbard et al., 2001). I encountered many occasions when my conversations with firefighters trespassed into such territory and I frequently worried about how this might affect them. Murphy and Dingwall (2001) highlight that ethical dilemmas are also presented when choosing what to publish. They suggest that by its nature, ethnographic research involves a small number of research settings and therefore there is a greater risk that the identity of the participants might be made visible. They note that participants may have shared information which could be misinterpreted or reframed by others and therefore damage their image. Indeed, as I entered the writing stage of my research, my emotional encounters did not become less intense. I continued to feel guilty about how I should present my research findings without exposing the identity of either the organisations I had worked with or the individuals who had offered up such rich and detailed accounts of their experiences. To further exacerbate these feelings of guilt, my writing coincided with a series of government reforms and also a period of 
industrial action which were having a major impact in this sector. I therefore attached asensitivity to my research that others who were less emotionally involved did not fully understand or appreciate. I found it difficult to write a linear text (Hammersley and Atkinson, 2007) that captured the different and sometimes contradictory versions of the truth (Crang and Cook, 2007) and the contextual politics and power struggles (Brewer, 2000) I had encountered. Indeed, Humphreys and Watson (2009) highlight that writing ethnography is challenging as there are different perspectives on what ethnography is and how it should be written which differ across the social sciences. In their examination of the range of ethnographic writing styles, they noted that ethnographies tend to range in style on a continuum from 'minimally manipulated' to 'highlight manipulated' or fictionalised accounts. They suggest that fictionalised ethnography enables researchers to publish highly sensitive data whilst still maintaining anonymity and confidentiality. I had opted to present my work as a mix of fictionalised ethnodrama and thematic arrangement (Hammersley and Atkinson, 2007) to alleviate some of the sensitivities I had attached to my research, however, this led to criticism and rejection from those unfamiliar with this style. Schwartz-Shea and Yanow (2014) highlight that although there is some agreement on the evaluation and quality criteria for ethnographic studies these tend to focus on the research design, fieldwork and analysis stages. They suggest that less attention is paid to the 'textwork' stage which they define as the presentation of a persuasive manuscript to a range of reader-reviewers who will determine if and how the work will be published. Schwartz-Shea and Yanow (2014, p. 58) therefore highlight that in a discipline characterised by 'positivist-orientated editorial positions' openness to ethnographic texts varies considerably and there is a danger that such texts 'will be held up to criteria more appropriate for positivist science and its presuppositions' and as such, deemed to lack scientific rigour. They therefore argue that authors need to be more persuasive and explicit regarding the trustworthiness of their scripts and should not naively rely on assumed tacit understandings as to how ethnographic texts should be presented.

\section{Conclusion}

Conducting ethnographic research is emotional and yet published accounts of these emotions remain sparse (Koning and Ooi, 2013; Van Maanen, 2010a). Rather than present ethnography as a straight forward process sanitized of emotion, I have provided a glimpse into the problems and dilemmas I encountered during my ethnographic research and also the range of 
emotions I experienced throughout the various stages of my research study providing some new insights into the difficulties encountered as an ethnographer. In sharing my experiences, my intention is not to engage in self-indulgent introspection (Van Maanen et al., 1993) but to be open and reflexive about the emotional nature of ethnographic research. With limited reference to emotions presented in the 'how to' methodology texts (Broussine et al., 2014; Clarke et al., 2014), there is a need for more ethnographers to take up the challenge of sharing their emotions, awkward encounters and 'problematics' (Koning and Ooi, 2013; Whiteman et al., 2009; Ybema et al., 2009) to prepare new researchers for the emotions they may encounter throughout the various stages of an ethnographic study. This sharing is important for the further advancement of the discipline because if ethnographic researchers are unprepared for the emotions they may encounter, they may feel incompetent and inadequate as ethnographers (Clarke et al., 2014; Hubbard et al., 2001; Mazzetti, 2013) and eschew ethnographic research in favour of other types of research (Van Maanen, 2010a). Additionally, by highlighting the emotional, it is hoped that practice will be informed by stimulating deep reflection in those responsible for the development of research programmes and supervision of researchers (Broussine et al., 2014).

Finally, it is also important to highlight that being attuned to our 'emotional radar' enables us to investigate and explore issues in more depth which may have a direct impact in the advancement of theory and practice (Whiteman et al., 2009). It is therefore time to acknowledge emotions as an integral part of the research process (Grisoni and Broussine, 2014) and realise their part in the creation of new insights and knowledge which can ultimately deepen our interpretation and analysis of fieldwork encounters (Whiteman et al., 2009). 


\section{References}

Brannan, M. (2014) Research as an emotional journey, in Clarke, C., Broussine M., and Watts, L. (eds. Researching with Feeling: The Emotional Aspects of Social and Organizational Research, London: Routledge.

Brewer, J. (2000). Ethnography. Berkshire: Open University Press.

Broussine, M., Watts, L., and Clarke, C. (2014) Why Should Researchers Be Interested in Their Feelings? in Clarke, C., Broussine M., and Watts, L. (eds.) Researching with Feeling: The Emotional Aspects of Social and Organizational Research, London: Routledge.

Clarke, C., Broussine M., and Watts, L. (2014) Researching with Feeling: The Emotional Aspects of Social and Organizational Research, London: Routledge.

Clarke, C. and Knights, D. (2014) Negotiating Identities in Clarke, C., Broussine M., and Watts, L. (eds.) Researching with Feeling: The Emotional Aspects of Social and Organizational Research, London: Routledge.

Crang, M., and Cook, I., 2007, Doing Ethnographies. London: SAGE Publications Ltd.

Dickson-Swift, V., James, E., and Liamputtong, P. (2008). Undertaking Sensitive Research in Health and Social Sciences: Managing Boundaries, Emotions and Risks. Cambridge: Cambridge University Press.

Down, S., Garrety, K., \& Badham, R. (2006). Fear and loathing in the field: Emotional dissonance and identity work in ethnographic research. Management, 9, 87-107.

Dundon, T. and Ryan, P. (2010) Interviewing Reluctant Respondents: Strikes, Henchmen, and Gaelic Games, Organizational Research Methods, 13, 562-581.

Emerson, R., Fretz, R., and Shaw, L. (2001). Participant Observation and Fieldnotes. In Atkinson, P., Coffey, A., Delamont, S., Lofland, J. and Lofland, L. (Eds.), Handbook of Ethnography. London: SAGE Publications Ltd.

Fine, G. A. and Shulman, D. (2009) Lies from the field: Ethical issues in organizational ethnography, in Ybema, S., Yanow, D. Wels, H. and Kamsteeg, F. (eds) Organizational Ethnography, London, SAGE Publications Ltd. pp. 177-195.

Grisoni, L. And Broussine, M. (2014) Emotionally Charged Research in Clarke, C., Broussine M., and Watts, L. (eds.) Researching with Feeling: The Emotional Aspects of Social and Organizational Research, London: Routledge.

Hammersley, M., \& Atkinson, P. (2007). Ethnography. King’s Lynn: MPG Books Group.

Hoffmann, E. (2007). Open-Ended Interviews, Power and Emotional Labour. Journal of Contemporary Ethnography, 36, 318 - 346.

Hubbard, G., Backett-Milburn, K., and Kemmer, D. (2001). Working with emotion: issues for the researcher in fieldwork and teamwork. International Journal of Social Research Methodology, 4, 119-137. 
Humphreys, M. and Watson, T. (2009) Ethnographic practices: From 'writing-up ethnographic research' to 'writing ethnography' in Ybema, S., Yanow, D. Wels, H. and Kamsteeg, F. (eds) Organizational Ethnography, London, SAGE Publications Ltd. pp. 4055.

Kleinman, S., and Copp, M. (1993). Emotions and Fieldwork, Qualitative Research Methods Series 28: London: SAGE Publications.

Kleinman, S. (1991). Field-Workers' Feelings: What We Feel, Who We Are, How We Analyse. In Shaffir, W., \& Stebbins, R. (Eds.), Experiencing Fieldwork: An Inside View of Qualitative Research. London: SAGE Publications. pp. 184-195.

Mazzetti, A. (2013). Occupational Stress Research: Considering the Emotional Impact for the Qualitative Researcher. Research in Occupational Stress and Well Being: Role of Emotion and Emotional Regulation, 11, 287-313.

Milton, K., and Svašek, M. (eds), Mixed Emotions: Anthropological Studies of Feeling. Oxford: Berg.

Moeran, B. (2009) From participant observation to observant participation, in Ybema, S., Yanow, D. Wels, H. and Kamsteeg, F. (eds.) Organizational Ethnography, London, SAGE Publications Ltd. pp.139-155.

Mohrman, S. (2010). Emotions, values, and methodology: Contributing to the nature of the world we live in whether we intend to or not. Journal of Management Inquiry, 19, $345-347$.

Murphy, E., and Dingwall, R. (2001). The Ethics of Ethnography. In Atkinson, P., Coffey, A., Delamont, S., Lofland, J., \& Lofland, L. (eds.), Handbook of Ethnography. London: SAGE Publications Ltd.

Pink, S. (2009) Doing Sensory Ethnography. London: SAGE Publications Ltd.

Schwartz-Shea, P and Yanow, D. (2009) Reading and writing as method: In search of trustworthy texts, in Ybema, S., Yanow, D. Wels, H. and Kamsteeg, F. (eds.) Organizational Ethnography, London, SAGE Publications Ltd.pp.56-82.

Van Maanen, J., Manning, P., \& Miller, M. (1993). Editor's comments. In S. Kleinman \& M. Copp (Eds.), Emotions and fieldwork (Vol. 28). Qualitative Research Methods. London: Sage.

Van Maanen, J. (2010a). You gotta have a grievance: Locating heartbreak in ethnography. Journal of Management Inquiry, 19, 338-341.

Van Maanen, J. (2010b). Tales of the field, on writing ethnography. Chicago, IL: University of Chicago Press

Waddington, D. (2004). Participant observation. In C. Cassell \& G. Symon (eds.), Essential guide to qualitative methods in organizational research. London: Sage. 
Watson, T. (2011). Ethnography, Reality, and Truth: The Vital Need for Studies of 'How Things Work' in Organisations and Management. Journal of Management Studies, 48, 202217.

Watts, L. (2014) A Psychosocial Approach to Researching with Feeling in Clarke, C., Broussine M., and Watts, L. (eds.) Researching with Feeling: The Emotional Aspects of Social and Organizational Research, London: Routledge.

Whiteman, G., Mu“ 1ler, T., \& Johnson, J. (2009). Strong emotions at work. Qualitative Research in Organizations and Management: An International Journal, 4, 46-61.

Ybema, S., Yanow, D. Wels, H. and Kamsteeg, F. (eds) (2009) Organizational Ethnography, London, SAGE Publications Ltd.

Ybema, S., Yanow, D. Wels, H. and Kamsteeg, F. (2009) Studying everyday organizational life, in Ybema, S., Yanow, D. Wels, H. and Kamsteeg, F. (eds) Organizational Ethnography, London, SAGE Publications Ltd. pp.1-20. 